\title{
Multipotential Stem Cells from the Adult Mouse Brain Proliferate and Self-Renew in Response to Basic Fibroblast Growth Factor
}

\author{
Angela Gritti, ${ }^{1}$ E. A. Parati, ${ }^{1}$ L. Cova, ${ }^{1}$ P. Frolichsthal, ${ }^{1}$ R. Galli, ${ }^{1}$ E. Wanke, ${ }^{2}$ L. Faravelli, ${ }^{2}$ D. J. Morassutti, ${ }^{3}$ \\ F. Roisen, ${ }^{3}$ D. D. Nickel, ${ }^{4}$ and Angelo L. Vescovi ${ }^{1}$ \\ ${ }^{1}$ Laboratory of Cellular Neuropharmacology, National Neurological Institute C. Besta, 20133 Milan, Italy, ${ }^{2}$ Department of \\ Physiology and Biochemistry, University of Milan, 20133 Milan, Italy, and ${ }^{3}$ Departments of Neurosurgery and Anatomy \\ and ${ }^{4}$ Department of Medical Biochemistry, Faculty of Medicine, University of Calgary, Calgary, Alberta, Canada T2N 4N1
}

It has been established that the adult mouse forebrain contains multipotential (neuronal/glial) progenitor cells that can be induced to proliferate in vitro when epidermal growth factor is provided. These cells are found within the subventricular zone of the lateral ventricles, together with other progenitor cell populations, whose requirements for proliferation remain undefined. Using basic fibroblast growth factor (bFGF), we have isolated multipotential progenitors from adult mouse striatum. These progenitors proliterate and can differentiate into cells displaying the antigenic properties of astrocytes, oligodendrocytes, and neurons. The neuron-like cells possess neuronal features, exhibit neuronal electrophysiological properties, and are immunoreactive for GABA, substance $P$, choline acetyltransferase, and glutamate. Clonal analysis confirmed the multipotency of these bFGF-dependent cells. Most significantly, subcloning experiments demonstrated that they were capable of self-renewal, which led to a progressive increase in population size over serial passaging. These results demonstrate that bFGF is mitogenic for multipotential cells from adult mammalian forebrain that possess stem cell properties.

Key words: stem cells; FGF; adult progenitors; neurogenesis; neuroplasticity; growth factors
The generation of neurons and glia of the mature central nervous system (CNS) is believed to end by early postnatal life (Raedler and Raedler, 1978; McConnell, 1988; McKay, 1989). The generation of new neurons, however, has been described in the hippocampus, the olfactory bulb (Altman, 1962; Altman and Das, 1965; Altman, 1969; Kaplan and Hinds, 1977; Bayer et al., 1982; Altman and Bayer, 1990; Corotto et al., 1993), and the cortex of adult rodents (Kaplan, 1981; Huang and Lim, 1990).

Proliferating cells have been identified in the subependyma of the lateral ventricles of the adult mammalian forebrain (Allen, 1912; Smart, 1961; Smart and Leblond, 1961; Privat and Leblond, 1972; Sturrock and Sinar, 1980). It has been proposed that the fate of half the progeny of these cells is death (Morshead and van der Kooy, 1992). It has been suggested, however, that the subependymal cell progeny contribute new glia to the brain parenchyma in adult rodents (Smart, 1961; Lewis, 1968; Blakemore, 1969; Privat and Leblond, 1972; Patterson et al., 1973). Furthermore, Lois and Alvarez-Buylla (1993) have demonstrated that the proliferating subependymal cells possess a broader neural developmental potential, because they differentiate into both neurons and glia in vitro, whereas in vivo they contribute new neurons in the postnatal (Luskin, 1993) and adult olfactory bulb (Okano et al., 1993; Lois and Alvarez-Buylla, 1994).

The growth factors that regulate the development of embryonic

Received June 19. 1995; revised Oct. 2, 1995; accepted Oct. 20, 1995.

This work was supported by Grant ICS49.2/RF93.42 from the Italian Ministry of Health. We thank Drs. E. Cattaneo and R. McKay for kindly providing the antinestin antibody, and Drs. P. Petruz and R. Spreafico for the anti-glutamate antiserum. We thank Drs. E. DiCicco-Bloom and R. McKay for reviewing a previous version of this manuscript, and Dr. D. C. Ward for critical revicw of English.

Correspondence should be addressed to Dr. A. L. Vescovi, Laboratory of Cellular Ncuropharmacology, National Neurological Institute C. Besta, Via Celoria 11, 20133 Milatı. Ilialy.

Copyright 1996 Socicty for Neuroscience 0270-6474/96/161074-10\$05.00/0 precursors might control the proliferation of progenitors in the mature CNS. For instance, epidermal growth factor (EGF) stimulates the proliferation of multipotent precursor cells from both the embryonic (Anchan et al., 1991; Lilien and Cepko, 1992; Reynolds et al., 1992) and the adult CNS (Rcynolds and Wciss, 1992). It has been shown recently that these adult EGF-responsive cells are stem cells, existing in a relatively quiescent state in the forebrain subependyma where they generate the constitutively proliferating precursor cells (Morshead et al., 1994). This finding suggests the existence of multiple types of progenitors in the adult mouse subependyma (Morshead et al., 1994) and raises questions concerning their developmental potential. Specifically, which factors govern their activity? Do these precursors generate different neural lineages, and do they possess self-renewal capacity?

Basic fibroblast growth factor (bFGF) stimulates the proliferation of various embryonic neural progenitors (for review, see Baird, 1994). It has been reported, however, that bFGF cannot induce the proliferation of stem cells isolated from the adult mouse striatum (Reynolds and Weiss, 1992). We have found recently that cultured EGF-responsive stem cells of the adult mouse striatum generate precursors that proliferate when exposed to bFGF (Gritti et al., 1995). Because these precursors can generate both neurons and glia, we re-examined the possibility that multipotential bFGF-responsive cells can be found in the adult CNS. We demonstrated that the adult mouse striatum contains precursors that proliferate in response to bFGF, undergoing self-renewal and increasing in number after subculturing. We showed further, via clonal analysis, that these bFGFdependent cells are multipotent and generate astroglial, oligodendroglial, or neuronal progeny.

\section{MATERIALS AND METHODS}

Isolation of adult brain cells. CD-1 albino mice (3- to 8-month-old) were anesthetized by intraperitoneal injection of $120 \mathrm{mg} / \mathrm{kg}$ pentobarbital and 
killed by cervical dislocation. The brains were removed and placed in artificial CSF (aCSF) containing (in $\mathrm{mm}$ ): $124 \mathrm{NaCl}, 5 \mathrm{KCl}, 1.3 \mathrm{MgCl}, 0.1$ $\mathrm{CaCl}_{2}, 26 \mathrm{NaHCO}_{3}$, and 10 D-glucose, $\mathrm{pH} 7.3$, acrated with $95 \% \mathrm{O}_{2} / 5 \%$ $\mathrm{CO}_{2}$ at room temperature. Striatal tissuc, including subependyma, was dissected out. cut with scissors into $1 \mathrm{~mm}^{3}$ sections, transferred into $30 \mathrm{ml}$ of aCSF containing $1.3 \mathrm{mg} / \mathrm{ml}$ trypsin (Type XII, 9000$) \mathrm{U} / \mathrm{mg}$; Sigma, St. Louis, MO), $0.67 \mathrm{mg} / \mathrm{ml}$ hyaluronidase $(200) \mathrm{U} / \mathrm{mg}$; Sigma), and 0.2 $\mathrm{mg} / \mathrm{ml}$ kynurenic acid (Sigma) and incubated under continuous oxygenation and stirring for 90 min at $32-34^{\circ} \mathrm{C}$. Tissue sections then were rinsed in aCSF for 10 min, transferred to Dulbecco's modified Eagle's medium (DMEM)/F12 (1:1, v/v: Life Technologies, Gathersburg, MD) containing $0.7 \mathrm{mg} / \mathrm{ml}$ ovomucoid (Sigma), and carcfully triturated with a firepolished Pasteur pipette. Cells were collected by centrifugation and resuspended in growth factor-free, chemically defined DMEM/F12 medium containing $2 \mathrm{~mm}$ l.-glutamine, $0.6 \%$ glucose, $9.6 \mathrm{gm} / \mathrm{ml}$ putrescine, $6.3 \mathrm{ng} / \mathrm{ml}$ progesterone, $5.2 \mathrm{ng} / \mathrm{ml}$ sodium selenite, $0.025 \mathrm{mg} / \mathrm{ml}$ insulin, $0.1 \mathrm{mg} / \mathrm{ml}$ transferrin, and $2 \mu \mathrm{g} / \mathrm{ml}$ heparin (sodium salt, grade II, Sigma; control medium). This procedure yielded $\sim 10^{5}$ viable cells per striatum.

Cell cultures and bFGiF-dependent cell propagation. Viable cells $(5000)$ were plated in $60 \mathrm{~mm}$ Petri dishes (Dow Corning, Corning, NY) at -200 cells $/ \mathrm{cm}^{2}$ in control medium or in the presence of $20 \mathrm{ng} / \mathrm{ml}$ human recombinant bFGF (Gibco, Grand Island, NY or U.S. Biochemicals, Cleveland. $\mathrm{OH}$ ), $20 \mathrm{ng} / \mathrm{ml}$ EGF (from mouse submaxillary gland, Sigma), $20 \mathrm{ng} / \mathrm{ml}$ human recombinant platelet-derived growth factor-BB (PDGFBB) (U.S. Biochemicals), or $100 \mathrm{ng} / \mathrm{ml}$ nerve growth factor (NGF; from mouse submaxillary gland, Sigma). Every 4 d, half of the medium was replaced with appropriate fresh medium. The number of primary spheres generated in each well was assessed $21 \mathrm{~d}$ after plating (DAP). bFGFgenerated spheres were collected by centrifuging for $10 \mathrm{~min}$ at $800 \times \mathrm{g}$ Some primary spheres were processed for triple-antigen immunofluorescence assay and subeloning experiments (see below), and the remainder wats dissociated mechanically to a single-cell suspension and replated for bulk cultures $\left(10000-20(0)\right.$ eclls $\left./ \mathrm{cm}^{2}\right)$. By 21 DAP, new spheres were formed that could undergo further passaging.

Cloning and serial subloming procedure. Individual bFGF-generated primary spheres were transferred into conical-bottom tubes (1 sphere/ tube), mechanicatly dissociated to a single-cell suspension, and plated onto a $35 \mathrm{~mm}$ Petri dish in the presence of bFGF. Viable cells were chesen on the basis of round shape, phase brightness, and lack of processes and were transferred into four-well chamber slides ( I cell/well Nunc. Naperville, IL) via heat-polished glass microelectrode pipettes (internal tip diameter $40-70 \mu \mathrm{m}$ ). Cells were fed every $4 \mathrm{~d}$. Approximately $5 \%$ of plated cells proliferated to give rise to secondary clonal spheres by 20-25 DAP; these were transferred onto poly-I-ornithine (poly-o)-coated glass coverslips ( 1 sphere/coverslip), grown for $5 \mathrm{~d}$ with bFGF, left for $5 \mathrm{~d}$ in control medium, and processed for triple-antigen indirect immunofluorescence.

For subcloning experiments, individual $21 \mathrm{~d}$ in vitro (DIV) primary spheres were transferred to $5 \mathrm{ml}$ microfuge tubes (1 sphere/tube), mechanically dissociated to a single-cell suspension, and plated (200) viable cells $/ \mathrm{cm}^{2}$ ) in a $60 \mathrm{~mm}$ Petri dish containing bFGF. After dissociation, cell viability was $\sim 50 \%$, as assessed by trypan blue exclusion; $20-30 \%$ of the viable cells proliferated and gave rise to secondary spheres, and the number of these cells in each dish was assessed at 21 DAP. Some of the secondary spheres were plated onto glass coverslips (1 sphere/coverslip) and processed for triple-antigen immunofluorescence assay. The remainder underwent a second subcloning step. The number of tertiary spheres and their capacity to generate neurons and glia were assessed as described for secondary spheres (Fig. 1; see Table 2).

Karyodye analysis. Cells were prepared by in sim harvesting after $2 \mathrm{hr}$ exposure to Colcemid $(0.1 \mu \mathrm{g} / \mathrm{ml})$, hypotonic treatment for $20 \mathrm{~min}(0.075$ $\mathrm{M} \mathrm{KCl}$ ), and fixation in $3: 1$ methanol/acetic acid. Mitotic chromosome spreads were analyzed by G-banding following the technique of Islam and Levan (1987). The modal number was determined by counting 30 intact metaphase spreads, and five G-banded spreads were assessed for karyotype status.

Immunocyochemistry. Single bFGF-generated spheres grown on poly-0-coated glass coverslips were fixed for $20 \mathrm{~min}$ with $4 \%$ p-formaldehyde in PBS, $\mathrm{pH} 7.4$, and rinsed three times with PBS. Coverslips then were incubated for $90 \mathrm{~min}$ at $37^{\circ} \mathrm{C}$ in PBS containing $10 \%$ normal goat serum (NGS), $0.3 \%$ Triton X-100, and the appropriate primary antibodies or antisera. After thorough washing with PBS/ 10\% NGS, cells were reacted for $45 \mathrm{~min}$ at room temperature (RT) with secondary fluorescein isothiocyanate (FITC)- or rhodamine (TRITC)-conjugated goat anti-mouse or anti-rabbit IgG antibodies

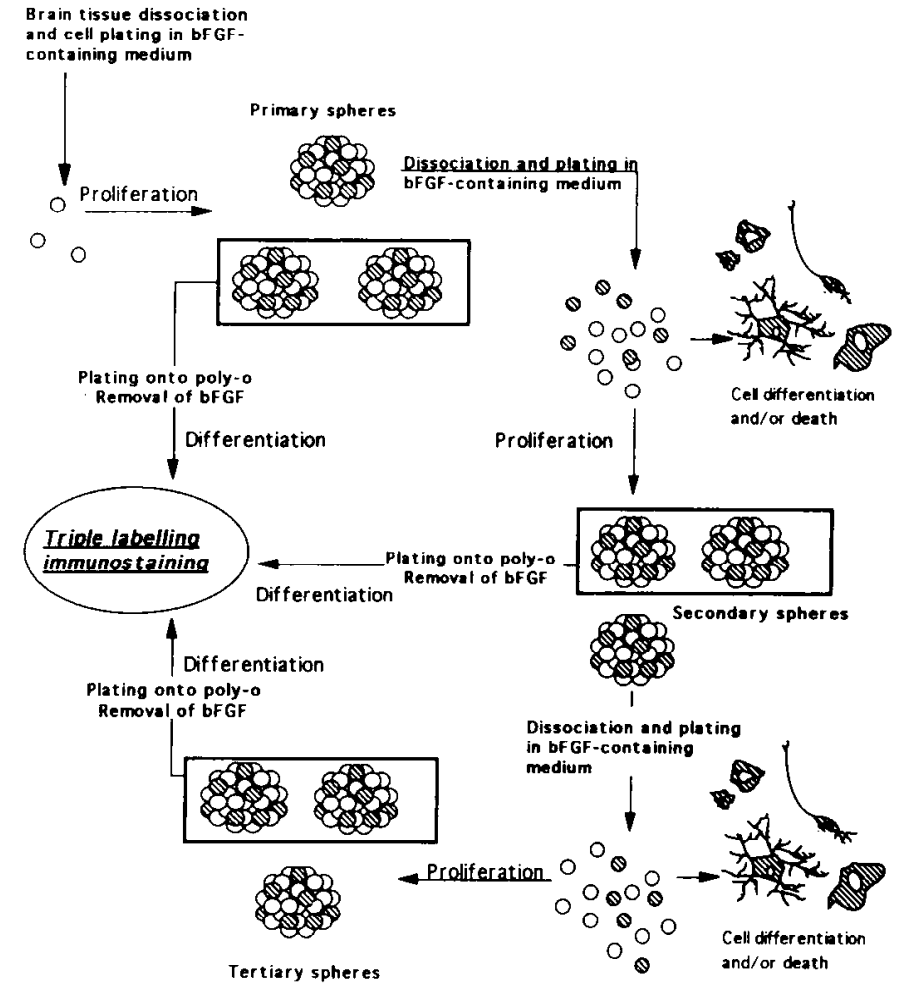

Figure 1. Experimental protocol for assessing self-renewall capacity of adult striatal bFGF-dependent stem cells. Individual cells from adult mouse striatum proliferated (Proliferation) in response to bFGF and produced spheres of nestin-IR cells under clonal culture conditions (Primary spheres; see also Fig. 2). Each sphere contained cells that could differentiate (Differentiation) into neurons, astroglia, or oligodendroglia when grown on poly-o-coated glass coverslips $(p o / y-o)$ without bFGF When individual primary spheres were dissociated and replated as single cells under clonal conditions in bFGF-containing medium, some cells either differentiated to acquire the typical morphology of neuronal or glial cells or died $(\bigcirc)$. However, a subset of cells proliferated (O; see also Table 2) and gave rise to Secondary spheres. Most of the secondary spheres were found to include neurons, oligodendroglia, and astroglia (Table 2). Secondary spheres not processed for immunolabeling underwent a second round of subcloning in bFGF-containing medium. Cell proliferation still occurred, as did cell death and differentiation, causing the formation of Tertiary spheres containing neurons and both major glia types (Table 2). Note that at each subcloning step an individual founder cell gave rise to one sphere which, in turn, contained more than one new founder (i.e., sphere-forming) cell (sec Table 2). These experiments demonstrate the existence of pluripotent precursor cells in the adult mousc CNS that proliferate in the presence of bFGF and are capable of self-renewal over serial passaging in vitro.

(1:100, Boehringer Mannheim, Indianapolis, IN) or with donkey antimouse IgM antibodics coupled to 7-amino-4-methylcoumarin-3-acetic acid (AMCA; 1:100, Jackson Immunorescarch, West Grove, PA). Coverslips were rinsed three times in PBS and once in distilled water and mounted on glass slides with Fluorsave (Calbiochem, Lal Jolla. (CA). The primary antibodies/antisera used were as follows: mouse monoclonal Rat 401 anti-nestin (gift from Drs. E. Cattaneo, University of Milan, and R. McKay, National Institutes of Health); mousc monoclonal anti-microtubule-associated protein-2 (MAP-2; $\operatorname{lgG}, 1: 100$, Boehringer); anti-tau microtubule-associated protein (Tau-1; IgG, 1:100, Boehringer); anti-neurofilament $160 \mathrm{kDa}$ (gift from Dr. E. Cattaneo); anti-galactocerebroside (GalC; IgG, 1:50, Boehringer); anti-O4 (IgM, 1:200, Boehringer); rabbit antisera against neuron-specific enolase (NSE; ready to use, Incstar, Tempe, AZ); glial fibrillary acidic protein (GFAP; ready to use, Incstar); GABA (1:5000), Sigma); substance $P$ (SP; 1:250, Incstar); methionine-enkephalin (Met-Enk; 1:250, Incstar); neuropeptide Y (NPY; 1:50, Boehringer); choline acetyl transferase (ChAT; 1:400, Chemicon, Temecula, CA): glutamic acid (1: 
20.000, gift from Dr. P. Petruz, University of North Carolina, through Dr. R. Spreafico, National Neurological Institute); and tyrosine hydroxylase (TH; 1:200, Epicenter Technologies, Madison, WI). For triple-labeling, immunocytochemistry cells were permeabilized for 5 min in PBS $/ 0.3 \%$ Triton $\mathrm{X}-100 / 10 \%$ NGS and incubated with a solution containing mouse anti-MAP-2 and rabbit anti-GFAP in PBS/NGS. Cells then were reacted with anti-mouse TRITC-conjugated and antirabbit FITC-conjugated secondary antibodies. After thorough washing, cultures were incubated with mouse anti-O4, followed by an incubation with donkey anti-mouse $\lg$ AMCA-conjugated secondary antibody. For thin-sectioning experiments, spheres were washed twice in $10 \mathrm{~mm}$ PBS, fixed in $4 \% p$-formaldehyde for 1 hr at RT, washed three times in $10 \mathrm{~mm}$ PBS for 5 min each, and then resuspended in $10 \%$ sucrose overnight. Spheres then were removed, placed in TBS tissuc-freezing media (Triangle Biomedical Scicnces, Durham, NC), and quick-frozen to $-50^{\circ} \mathrm{C}$. The spheres then were cut into $15 \mu \mathrm{m}$ serial sections on an IEC Autotome cryostat (Needham Heights, MA) and collected on gelatin-coated microscope slides. Nestin rabbit polyclonal antibody diluted to $1: 1000$ was applied to the serially cut spheres overnight at $5^{\circ} \mathrm{C}$. Sections were washed three times, and donkey anti-rabbit FITCconjugated antibody (1:20, Amersham, Buckinghamshire, UK) was added for $1 \mathrm{hr}$ at RT. After three washes ( 5 min cach), the sections were incubated in Hocchst $33258(15 \mu \mathrm{g} / \mathrm{ml}$, Sigma $)$ for $20 \mathrm{~min}$ at $\mathrm{RT}$, washed, and coverslipped with antifade media. Samples were viewed and photographed with an inverted Zeiss Axiophot fluorescence microscope (Axon Instruments, Foster City, CA). No labeling was observed in control experiments in which primary antibodies/antisera were omitted or, alternatively, when normal nonimmune rabbit serum was used. Also, coverslips incubated with single primary antibodies/ antisera and followed by all three secondary steps exhibited immunoreactivity only with the appropriate filter. Therefore, there was no evidence of cross-reactivity.

Cell subtype composition and nearotransmitter phenotype in $b F G F$ generated spheres. Individual bFGF-generated spheres that underwent triple-labeling immunocytochemical assay were examined using indirectfluorescence microscopy. The number of GFAP-, MAP-2-, and O4immunorcactive (IR) cells was assessed in 10 nonoverlapping fields in each sphere. The total number of cells in each field was determined by counterstaining cell nuclei with 4,6-diamidine-2-phenylindole dihydrochloride (DAPI; $1 \mathrm{mg} / \mathrm{ml}$ in methanol for $15 \mathrm{~min}$ at $37^{\circ} \mathrm{C}$ ). Also, single bFGF-generated spheres were labeled with rabbit polyclonal antisera recognizing specific neurotransmitters, neuropeptides, or enzymes, as described above.

Electrophysiological analysis. First- to third-passage bFGF-generated spheres were plated onto poly-o-coated glass coverslips in the presence of bFGF. At 5 DAP, bFGF-containing medium was exchanged for control medium and cells were cultured for an additional $5 \mathrm{~d}$ before transferring the coverslips to $35 \mathrm{~mm}$ Petri dishes. Cultures then were examined under the phase-contrast microscope, and cells displaying striking neuron-like morphology were chosen for electrophysiological recording. Fourteen cells were analyzed. They were maintained in physiological saline solution of the following composition (in $\mathrm{mM}$ ): $140 \mathrm{NaCl}, 3 \mathrm{KCl}, 2 \mathrm{CaCl}_{2}, 1 \mathrm{MgCl}_{2}$, 24 p-glucose, 10 HEPES, pH-adjusted to 7.3 with KOH. The pipette solution for whole-cell recording contained (in $\mathrm{mm}$ ): $140 \mathrm{~K}$-aspartate, 2 $\mathrm{MgCl}_{2}, 10 \mathrm{HEPES}, 5$ EGTA, $2 \mathrm{MgATP}$, pH-adjusted to 7.3 with $\mathrm{KOH}$.

Patch-clamp recordings. Electrodes with resistance of 3-4 M $\Omega$ were pulled with a multistage program on a Brown-Flaming-type puller (Sutter, Novato, CA) from borosilicate glass (Hilgenberg, Germany). Gigascal resistances were in the range 10-20 G $\Omega$. Recordings in voltage clamp and current clamp were done with a fast patch-clamp amplifier designed in our electronics department and tested in other experiments (Wanke et al., 1987). All recordings were at RT $\left(21-23^{\circ} \mathrm{C}\right)$, and Petri dishes were substituted every $30-45 \mathrm{~min}$. During acquisition and data analysis, pClamp (Axon) and Origin (Microcal, San Diego, CA) software were routinely used on a 486DX2-66 PC (Vobis, Milan, Italy).

\section{RESULTS}

\section{Undifferentiated cells from adult murine striatum proliferate in response to bFGF}

Adult tissue was dissected out from 3-to 8-month-old CD-1 male albino mice. A cut was made through the cortex into the lateral ventricles, and tissue that was dissected out comprised the entire nucleus caudatus, the putamen, and the lateral part of the globus pallidus. Special care was taken to avoid the removal of tissue from the corpus callosum. Cells were dissociated (see Materials and Methods) and plated as single cells at low density (200) cells $/ \mathrm{cm}^{2}$ ) in control medium or in medium containing $20 \mathrm{ng} / \mathrm{ml}$ EGF or bFGF. As described previously (Reynolds and Weiss, 1992), in the presence of EGF a few cells in each plate survived, underwent proliferation, and generated spheres of undifferentiated cells. Spheres of cells also were formed in the presence of 20 $\mathrm{ng} / \mathrm{ml}$ bFGF. Under these conditions, $\sim 1 \%$ of the total cells plated survived, became hypertrophic and phase-bright (2 DIV; Fig. $2 A$ ), and began to divide (5 DIV; Fig. $2 B$ ), continuing ( 12 DIV; Fig. 2C) until a spherical cluster of cells formed and lifted off the substrate (21 DIV; Fig. 2D). No significant difference was found between the number of spheres per plate generated in response to EGF and bFGF ( $68 \pm 9$ vs $58 \pm 11$, respectively; $n=$ 8 independent cultures; 4 mouse striata were pooled in each experiment). Conversely, in control medium or in the presence of saturating concentrations of PDGF-BB or NGF, no proliferation was observed and all of the cells died by 4 DIV.

The nature of the cells in the bFGF-generated primary spheres was determined by transferring individual 21 DIV spheres onto poly-o-coated glass coverslips and processing them for immunocytochemistry $1-2 \mathrm{hr}$ after plating (Fig. $2 E$ ). None of the cells in the spheres was IR for GFAP (a specific astroglial marker; see Raff et al., 1983), the neuronal antigens NSE and MAP-2, or GalC (a specific marker for oligodendrocytes; see Raff et al., 1978) (data not shown). Virtually all of the cells were IR for the neuroepithelial antigen nestin (Hockfield and McKay, 1985; Frederiksen and McKay, 1988; Genschwind and Hockfield, 1989; Tohyama et al., 1992) (Fig. 2F). Quantitative analysis performed on 15 - $\mu \mathrm{m}$-thick serial sections of bFGF-generated spheres showed that $99.98 \pm 0.2 \%$ of the total number of cells in the spheres were nestin-IR (a total of 8368 cells was counted in 8 spheres in 2 independent experiments). Thus, bFGF induced the proliferation of undifferentiated precursor cells from the adult mouse forebrain.

\section{bFGF-dependent cells from the adult murine striatum are multipotent and differentiate into neurons and glia}

We next investigated whether undifferentiated cells within $\mathrm{b} \Gamma \mathrm{G} F$ generated primary spheres could differentiate into the three major cell types found in the mature CNS. Individual 21 DIV spheres were transferred onto glass coverslips in the presence of $\mathrm{bFGF}$ (Fig. 3A). During the first 5 DAP, cell division continued and the size of the sphere increased; cells also migrated away from the core of the sphere (2 DAP; Fig. 3B). At 5 DAP, bFGF-containing medium was replaced with control medium, and cells were left for another $5 \mathrm{~d}$ before being processed for triple-antigen indirect immunocytochemistry to allow the simultaneous detection of neuronal and astroglial/oligodendroglial antigens (10 DAP; Fig. 3C) (see Discussion). This approach revealed the presence of GFAP (Fig. 3D)-, O4 (Fig. 3E)-, and MAP-2-IR cells (Fig. $3 L$ ) within the bFGF-generated primary spheres.

The relative proportion of cells expressing neuronal, astroglial, and oligodendroglial antigens was determined. At 10 DAP, 31.0 \pm $4.9 \%$ of the cells analyzed were GFAP-IR, $13.3 \pm 2.3 \%$ werc MAP-2-IR, and $5.83 \pm 2.6 \%$ were O4-IR (Table 1). Under identical experimental conditions, GalC-IR cells (Fig. $3 F$ ) also were detected, together with neuron-like cells expressing the neuronal antigens NSE (Fig. $3 G, H$ ), neurofilament $160 \mathrm{kDa}$ (NF160) (Fig. 3I), and Tau-1 (Fig. 3M), confirming the presence within each sphere of neuronal and oligodendroglial cells. Cells 

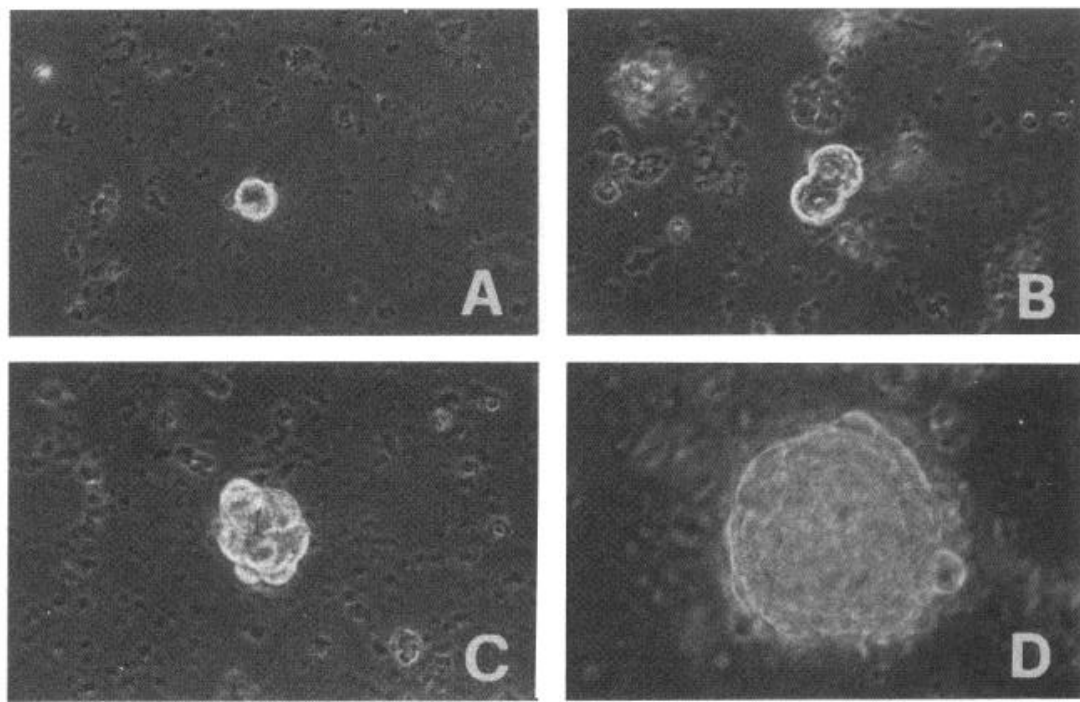

Figure 2. bFGF induces proliferation of undifferentiated cells isolated from the adult mouse striatum. Cells isolated from adult mouse striatum and cultured at clonal density (final density $<2$ cells $/ \mathrm{cm}^{2}$ ) in the presence of $20 \mathrm{ng} / \mathrm{ml}$ bFGF became hypertrophic by 2-3 DIV $(A)$ and underwent cell division by 5 DIV $(B)$. Proliferation continued and, after 10-12 DIV, small clusters of proliferating cells formed $(C)$ which, by 21 DIV, had increased in size and lifted off the substrate ( $D$; primary spheres). $E$, Phasecontrast photomicrograph of a 21 DIV bFGF-generated sphere $1 \mathrm{hr}$ after plating onto a poly-o-coated glass coverslip. $F$, The cells in the sphere shown in $E$ are IR for nestin, and quantitative analysis showed that $99.98 \pm 0.2 \%(n=$ 8 ) of total cells in primary spheres displayed anti-nestin immunoreactivity (see Results). Scale bar (shown in $E$ ), $25 \mu \mathrm{m}$.
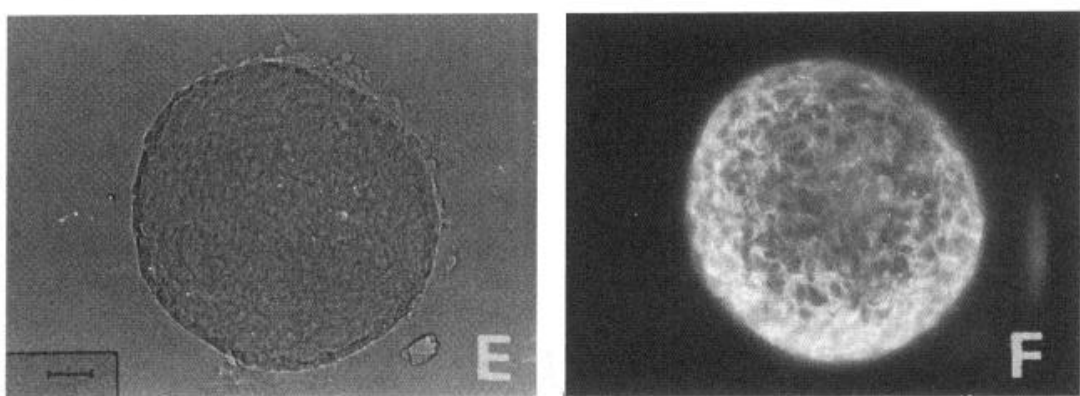

non-IR for NSE, Tau-1 protein, GFAP, O4, or GalC were found to label with the anti-nestin antibody (data not shown). Of importance, glial and neuronal markers never colocalized within the same cell.

In conclusion, the adult mouse brain contains undifferentiated pluripotent precursors that, in response to bFGF, proliferate and generate spheres of cells that can differentiate into neurons, astrocytes, and oligodendrocytes.

\section{Self-renewal properties of multipotential bFGF- dependent cells of the adult CNS}

Self-renewal, or the capacity of a cell to generate progeny identical to itself, is a defining characteristic of stem cells (Hall and Watt, 1989; Potten and Loeffler, 1990). To demonstrate selfrenewal in our multipotent bFGF-dependent cells, we determined whether they produced multipotent progeny after serial subcloning (Fig. 1). A similar approach was used by Stemple and Anderson (1992) in their study on stem cells of the neural crest.

Individual bFGF-dependent cells from the primary culture (primary founder cells) gave rise to spheres of cells (primary spheres) (Figs. 1, 2). Thirteen of these primary spheres were subcloned, and the functional features of their progeny were assessed. When cells that were dissociated from individual primary spheres (secondary founders) were replated at clonal density in the presence of bFGF, some of the cells differentiated and some died. The surviving cells continued to proliferate, however, so that more than one secondary sphere was formed (Table 2, column 2). This demonstrates that the primary bFGF-dependent founder gave rise to more than one cell which, like the parent cell, responded to bFGF by forming new spheres. Of importance, the secondary founders also retained the pluripotency of the primary founder cells, as they gave rise to secondary clonal spheres, the cells of which could differentiate to neurons, astrocytes, and oligodendrocytes (Table 2, columns 3 and 4). When a second subcloning was performed on a randomly selected subset of secondary spheres (see Fig. 1), cells from an individual sphere (tertiary founders) gave rise to more than one tertiary sphere in response to bFGF (Table 2, column 6). Again, cells within tertiary spheres were capable of differentiating into neurons and both types of glia (Table 2, columns 7 and 8; Fig. 4) or, alternatively, they could generate new spheres in the continuous presence of bFGF (data not shown). Therefore, the tertiary founders possessed features identical to the secondary and primary founder cells. We emphasize that every time an individual sphere was subcloned, more than one new sphere was generated. This was the case regardless of whether the spheres used were from primary or serially passaged (up to the 11th generation) cultures (A. Gritti and A. Vescovi, unpublished data). Moreover, bFGF-dependent cells retained a normal karyotype over serial passaging; in fact, the karyotype was determined to be euploid $40, \mathrm{XY}$, in ninth-passage bFGF-dependent adult stem cultures, which is consistent with previous reports (Robertson et al., 1983; Hooper, 1992).

\section{Clonal analysis of the multipotency of bFGF- dependent striatal cells}

To demonstrate the multipotency of adult bFGF-dependent stem cells, we performed a clonal analysis. Individual bFGF-generated cells from primary, secondary, or tertiary spheres were transferred into four-well chamber slides ( 1 cell/well) (Fig. $4 A$ ). In the presence of bFGF, $\sim 5 \%$ of these single cells (Fig. $4 A$ ) proliferated and by 21 DAP gave rise to clonal spheres (Fig. $4 B$ ), which were transferred onto glass coverslips (Fig. $4 C$ ). Triple-labeling immunocytochemistry performed on these spheres $10 \mathrm{~d}$ later (Fig. $4 D, E)$ revealed the presence of MAP-2-, GFAP-, and O4-IR cells 

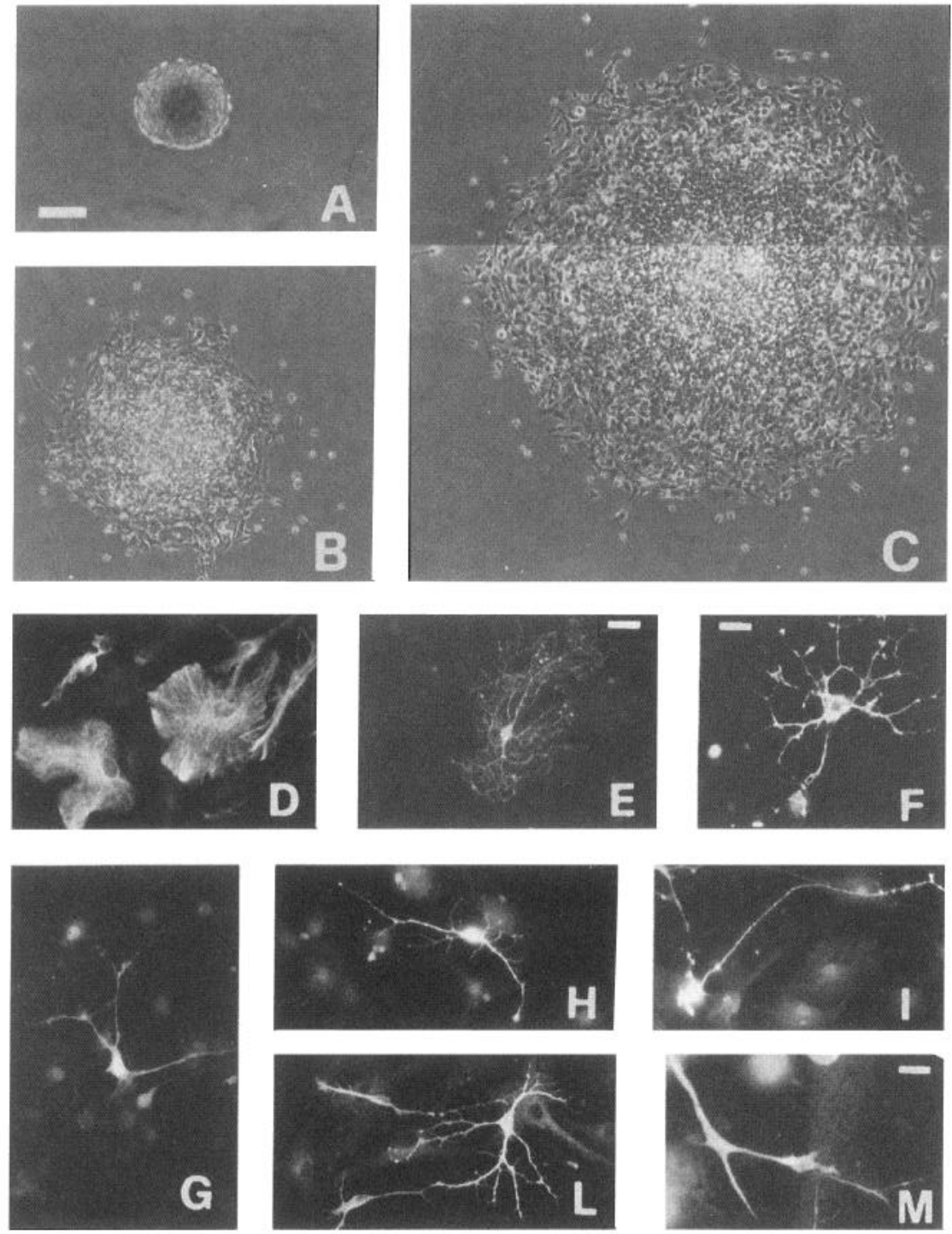

Figure 3. bFGF-dependent cells of the adult striatum generate cells displaying neuronal, astroglial, and oligodendroglial markers. A bFGF-generated primary sphere is shown $1 \mathrm{hr}(A)$ and $2 \mathrm{DAP}(B)$ onto a glass coverslip in bFGF-containing medium. At 5 DAP, the culture was switched to control medium. At 10 DAP $(C)$, indirect immunolabeling demonstrated the presence in the sphere of cells expressing antigens of the astroglial (GFAP, D), oligodendroglial $(\mathrm{O} 4, E)$, and neuronal lineage (MAP-2, $L$ ). Oligodendroglial (GalC, $F$ ) and neuronal (NF-160, I; Tau-1, $M$; NSE, $G, H)$ antigens were found in separate experiments performed using the same experimental protocol. Scale bar: $A-C, 100 \mu \mathrm{m}$ (shown in $A$ ); $D, E, I, 25 \mu \mathrm{m}$ (shown in $E$ ); $F, G, H, L, 16 \mu \mathrm{m}$ (shown in $F$ ); $M, 12 \mu \mathrm{m}$.
Table 1. Antigenic properties of bFGF-generated cells of the adult striatum

\begin{tabular}{cccc} 
& \multicolumn{3}{c}{ Number of IR cells/total cell number $(\%)$} \\
\cline { 2 - 4 } & MAP-2 & GFAP & O4 \\
\hline & $28 / 321(8.7)$ & $73 / 321(22.7)$ & $36 / 321(11)$ \\
& $75 / 451(16.6)$ & $180 / 451(40)$ & $17 / 451(3.8)$ \\
Mean \pm SE & $112 / 819(13.7)$ & $245 / 819(30)$ & $19 / 819(2.3)$ \\
& $13.3 \pm 2.3 \%$ & $31.0 \pm 4.9 \%$ & $5.83 \pm 2.6 \%$
\end{tabular}

Individual bFGF-generated primary spheres were transferred onto poly-o-coated glass coverslips and cultured for 5 DIV in bFGF-containing medium. This was replaced with control medium, and cells were grown for 5 more DIV before processing for triple immunolabeling. The number of MAP-2-, GFAP-, and O4-IR cells was determined in 10 nonoverlapping fields in each sphere. The total number of cells in each field was assessed by counterstaining with DAPI. Data are mean $\pm \mathrm{SE}$ of three independent experiments.

within each sphere (Fig. $4 F$ ), confirming the pluripotent nature of the clone founder cells.

\section{Neurotransmitter phenotype and electrophysiological properties of bFGF-generated neurons}

In primary, secondary, and tertiary passage cultures, GFAP-IR cells had the typical morphology of protoplasmic astroglia (Fig.
3D), whereas O4-IR (Fig. $3 E$ ) and GalC-IR (Fig. $3 F$ ) cells displayed tangled branches, symmetrically originating from a large, round cell body. Cells expressing neuronal antigens (Fig. 3G-M) possessed few long processes. We looked for the presence of CNS neurotransmitters, neuropeptides, amino acids, and neurotransmitter metabolic enzymes via indirect immunofluorescence. Neuron-like cells IR for GABA (Fig. $5 B$ ), glutamic acid (Fig. $5 A$ ), $\mathrm{SP}$ (Fig. $5 D$ ), and ChAT (Fig. $5 C$ ) were present in primary, secondary, and tertiary spheres. Immunoreactivity for NPY, TH, or Met-Enk was not observed.

We studied the cell-membrane excitability properties of the neuron-like cells derived from bFGF-dependent stem cells using the whole-cell patch-clamp technique under both current- and voltage-clamp configurations. The cell resting potential $\left(V_{\text {rest }}\right)$ observed in a total of 14 cells ( 3 independent experiments) was in the range of -52 to $-68 \mathrm{mV}$. In Figure 6 , data from a representative neuron-like cell are shown. In Figure $6 A$, recordings in current clamp display a typical action potential (AP) response defined by a threshold in the range of -32 to $-27 \mathrm{mV}$. In general, changes of the cell membrane potential, obtained by injection of small inward or outward holding currents, produced higher or smaller responses, respectively (Sontheimer and Waxman, 1992). The AP had a peak of $+6 \mathrm{mV}$, a duration of $1.85 \mathrm{msec}$ (at -20 


\begin{tabular}{|c|c|c|c|c|c|c|c|}
\hline $\begin{array}{l}\text { Primary } \\
\text { sphere } \\
\text { identity }\end{array}$ & $\begin{array}{l}\text { Number of } \\
\text { secondary } \\
\text { spheres }\end{array}$ & $\begin{array}{l}\text { Number of } \mathrm{N}+\mathrm{G} \\
\text { secondary } \\
\text { spheres }(\%)\end{array}$ & $\begin{array}{l}\text { Number of } \mathrm{N}+\mathrm{A}+\mathrm{O} \\
\text { secondary spheres } \\
(\%)\end{array}$ & $\begin{array}{l}\text { Secondary } \\
\text { sphere } \\
\text { identity }\end{array}$ & $\begin{array}{l}\text { Number } \\
\text { of tcrtiary } \\
\text { spheres }\end{array}$ & $\begin{array}{l}\text { Number of } \mathrm{N}+\mathrm{G} \\
\text { tertiary spheres } \\
(\%)\end{array}$ & $\begin{array}{l}\text { Number of } \mathrm{N}+\mathrm{A}+\mathrm{O} \\
\text { tertiary spheres }(\%)\end{array}$ \\
\hline 1.1 & $17^{\prime \prime}$ & $6(35)$ & $8(47)$ & $1.1 / 1$ & $26^{\prime \prime}$ & $7(27)$ & $16(61)$ \\
\hline 1.2 & 27 & $9(33)$ & $18(67)$ & $2.1 / 2$ & $35^{a}$ & $2(6)$ & $18(51)$ \\
\hline 2.1 & 14 & $5(36)$ & $8(57)$ & $3.1 / 3$ & 19 & $1(5)$ & $18(95)$ \\
\hline 2.2 & $44^{\prime \prime}$ & $9(20)$ & $28(67)$ & $3.3 / 1$ & 10 & $1(10)$ & $9(90)$ \\
\hline 3.1 & $37^{\prime \prime}$ & $6(16)$ & $24(65)$ & $3.4 / 1$ & $29^{\prime \prime}$ & $7(24)$ & $18(62)$ \\
\hline 3.2 & 20 & $5(25)$ & $15(75)$ & $3.4 / 2$ & $51^{a}$ & $4(8)$ & $37(72)$ \\
\hline 3.3 & 40 & $12(30)$ & $27(67)$ & $4.1 / 1$ & 37 & $8(22)$ & $29(78)$ \\
\hline 3.4 & 56 & $13(23)$ & $41(73)$ & $4.1 / 2$ & 59 & $13(22)$ & $46,(78)$ \\
\hline 3.5 & 47 & $9(19)$ & $38(81)$ & $4.1 / 3$ & 45 & $5(11)$ & $40(89)$ \\
\hline 4.1 & 45 & $9(20)$ & $33(73)$ & $4.2 / 1$ & $64^{\prime \prime}$ & $12(19)$ & $48(75)$ \\
\hline 4.2 & $144^{\prime \prime}$ & $15(10)$ & $90(62)$ & $4.2 / 2$ & $153^{\prime \prime}$ & $25(16)$ & $118(77)$ \\
\hline 4.3 & $115^{a}$ & $11(9)$ & $75(65)$ & $4.2 / 3$ & 73 & $15(20)$ & $58(80)$ \\
\hline \multirow[t]{2}{*}{4.4} & 41 & $3(7)$ & $38(93)$ & $4.2 / 4$ & 31 & $2(6)$ & $29(94)$ \\
\hline & & & & $4.2 / 5$ & $45^{\prime \prime}$ & $3(7)$ & $37(82)$ \\
\hline
\end{tabular}

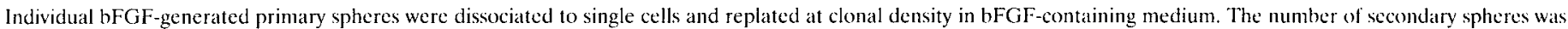

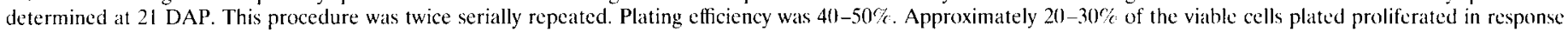

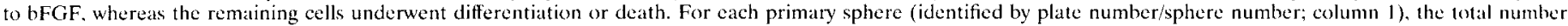

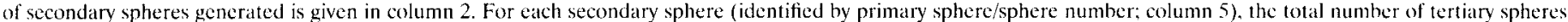

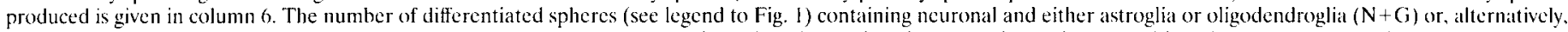

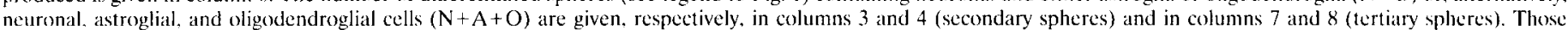

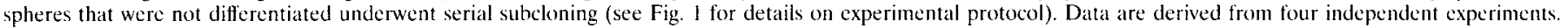

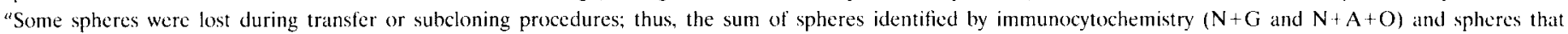
underwent further subcloning does not correspond to the total number of secondary or tertiary sphere given in the appropriate eolumn.

$\mathrm{mV}$ ), maximal rates of de- and repolarization of +40 and -42 $\mathrm{V} / \mathrm{sec}$, respectively, and an afterhyperpolarization of $-77 \mathrm{mV}$, suggesting the presence of active inward and outward membranc currents. Voltage-clamp recordings are shown in Figure $6 B$ that indicate the presence of typical fast inward and delayed outward currents. The inward currents were found to be tetrodotoxin (TTX)-sensitive ( $1 \mu \mathrm{M}$; data not shown). In the current-voltage plot shown in Figure $6 C$, the peak inward and steady-state outward current densities are displayed. In Figure $6 D$, the steadystate inactivation of the $\mathrm{Na}^{+}$conductance is plotted to show that at $V_{\text {rest }}, 100 \%$ of voltage-activated $\mathrm{Na}^{+}$channels are available for sustaining the regenerative response. With $\mathrm{d} V_{\mathrm{m}} / \mathrm{d} t=I_{\mathrm{Na}} / C_{\mathrm{m}}\left(C_{\mathrm{m}}\right.$ is the membrane capacitance), the maximal rate of rise of the AP shown in Figure $6 A$ is compatible with the current density in Figure $6 B$. Overall, data in Figure 6 show that cells with neuronal morphology are able to respond to putative EPSPs with typical APs in an all-or-none pattern. Thus, bFGF-generated spheres contain cells that can differentiate into cells possessing the electrophysiological features of ncurons.

\section{DISCUSSION}

Stem cells are defined as undifferentiated cells displaying high proliferative potential, generating a wide variety of differentiated progeny and, of more importance, possessing the capacity for self-renewal throughout the life of the adult animal (Hall and Watt, 1989; Potten and Loeffler, 1990). We isolated progenitor cells from the adult mouse brain that require bFGF to undergo proliferation in vitro and found that they satisfy the main criteria for classification as CNS stem cells. These cells are found in the adult animal and are undifferentiated and multipotent, because they can give rise to differentiated astroglia, oligodendroglia, and neuronal cells. Of importance, in response to bFGF these cells adopt a division mode that results in both self-renewal and expansive growth over serial passaging.
In our primary cultures, $\sim 1 \%$ of the total viable cells that were plated proliferatcd in response to bFGF and gave rise to spheres of round, undifferentiated cells that did not label with antibodies to neuronal or glial antigens, but were IR for the early neuroepithelial marker nestin (Frederiksen and McKay, 1988; Genschwind and Hockfield, 1989; Hockfield and McKay, 1985) (Fig, 2). Thus, bFGF-dependent CNS progenitors can be defined as proliferating undifferentiated cells because they lack the morphological features and antigenic markers characteristic of mature CNS cells. Of importance, these precursors were also multipotent, because the spheres they generated contained cells that could differentiate into those displaying antigenic markers for any of the three major CNS lineages (see below).

We assessed self-renewal in our bFGF-dependent cells by serial subcloning (Stemple and Anderson, 1992) and found that some individual cells from primary spheres generated new spheres and retained multipotentiality when replated at clonal density in the presence of bFGF; the remaining cells underwent cell differentiation or died (Table 2). When these experiments were repeated by passaging secondary spheres to generate tertiary clones, identical results were obtained (Table 2). These data show that bFGFdependent precursors possess self-renewal capacity. Although these experiments did not allow us to establish whether this capacity is unlimited, certain evidence suggests that this is the case. In our subcloning experiments, each bFGF-dependent cell was able to generate more than one stem progeny. Hence, the size of the bFGF-dependent stem cell population was expanding in our cultures. Second, although this phenomenon has been documented quantitatively only up to the third passage, all of the tertiary spheres contained bFGF-responsive precursors and could be propagated in bFGF-containing medium for $>8$ months ( 11 passages; A. Gritti and A. Vescovi, unpublished data). In these cultures, a steady increase in the total number of bFGF- 

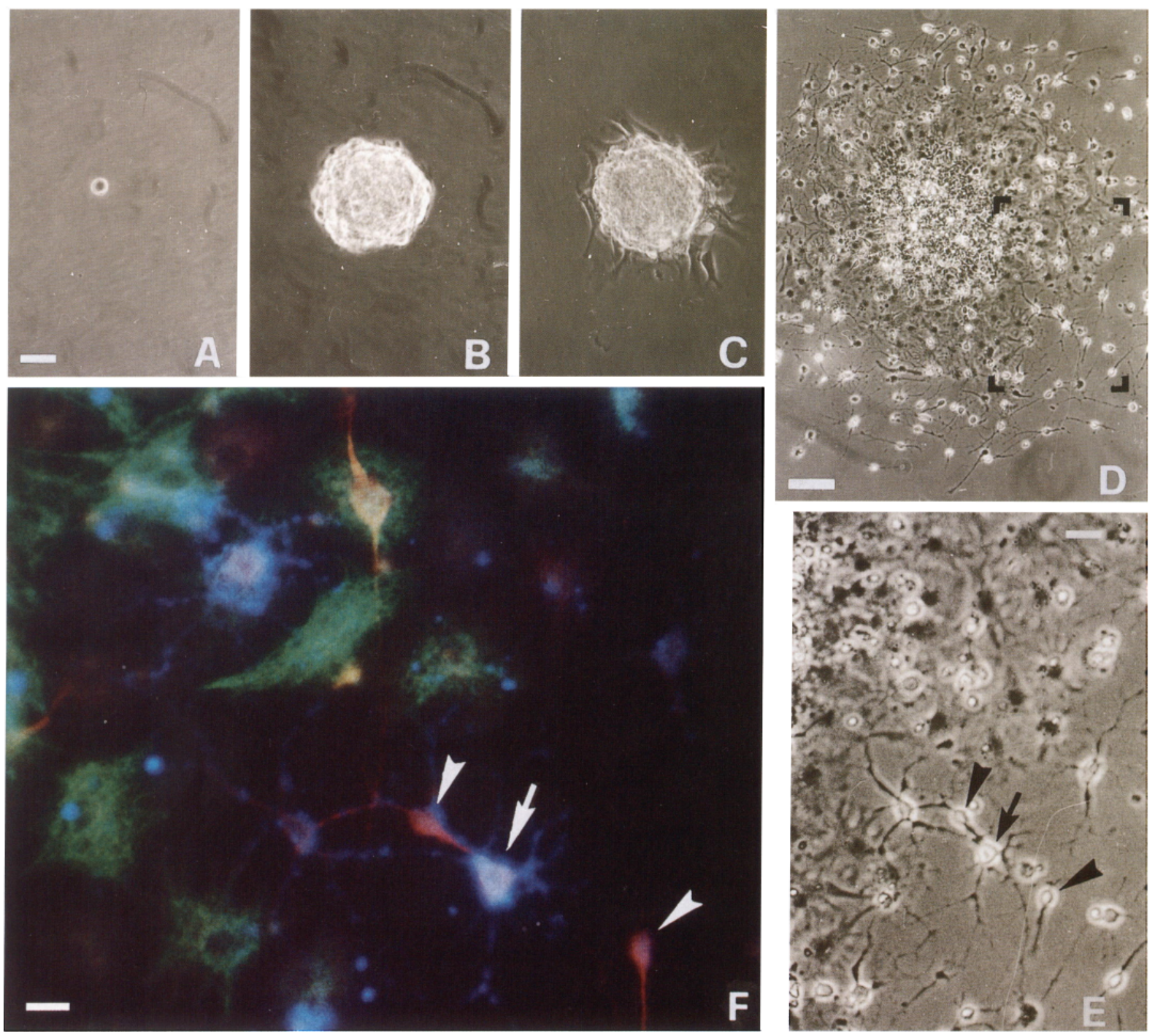

Figure 4. bFGF-dependent cells of the adult striatum are multipotent. Primary bFGF-generated spheres were dissociated mechanically, and cells were replated in the presence of bFGF. Twenty-four hours later, individual viable cells were transferred into $1 \mathrm{~cm}^{2}$ tissue culture wells (1 cell/well). The phase-bright, round cell shown in $A 2 \mathrm{hr}$ after plating gave rise, by $21 \mathrm{DAP}$, to a spherical clone of cells $(B)$. $C$, The same clonal sphere $1 \mathrm{hr}$ after being transferred onto an adhesive substrate in the continuous presence of bFGF. Five days later, bFGF-containing medium was replaced with control medium and culturing continued for 5 additional days $(D)$. High-power magnification of phase-contrast $(E)$ and fluorescence micrographs $(F)$ of the field bracketed in $D$ after triple-labeling immunofluorescence. Immunoreactivity for neuronal (MAP-2, red), oligodendroglial (O4, blue), and astroglial (GFAP, green) is found within the same sphere. Arrows and arrowheads identify the same cells in $E$ and $F$. Scale bars: $A-C, 25 \mu \mathrm{m}(\operatorname{shown}$ in $A) ; D, 100 \mu \mathrm{m} ; E, 50 \mu \mathrm{m}$; $F, 8 \mu \mathrm{m}$.

dependent cells that retained both multipotency and a normal karyotype was observed.

bFGF-dependent stem cells were found to be multipotential. When 21 DIV bFGF-generated spheres from primary or serially passaged cultures were plated onto coverslips and cultured with bFGF for an additional $10 \mathrm{~d}$, neuronal and glial cells were found in the cultures. However, only MAP-2 + O4 or, alternatively, MAP-2 + GFAP immunoreactivity could be detected within an individual sphere, the remaining cells of a sphere being nestin-IR. Nevertheless, some nestin-IR cells displayed clear astroglial or oligodendroglial morphology, which suggests that they were im- mature glia. This is in agreement with previous reports demonstrating that embryonic bFGF-dependent mixed neuronal/glial progenitors fail to express astroglial markers (Vescovi et al., 1993) and that bFGF prevents the differentiation/maturation of glial precursors in serum-free medium (Perraud et al., 1988). To assess the full developmental potential of individual bFGF-dependent precursors, single spheres were grown in the presence of bFGF for $5 \mathrm{~d}$ and then left for an additional $5 \mathrm{~d}$ in control medium. Triple-antigen immunofluorescence revealed that after removing bFGF, GFAP-, O4-, and MAP-2-IR (or, alternatively, Tau-1-IR) cells were present simultaneously in most of the bFGF-generated 

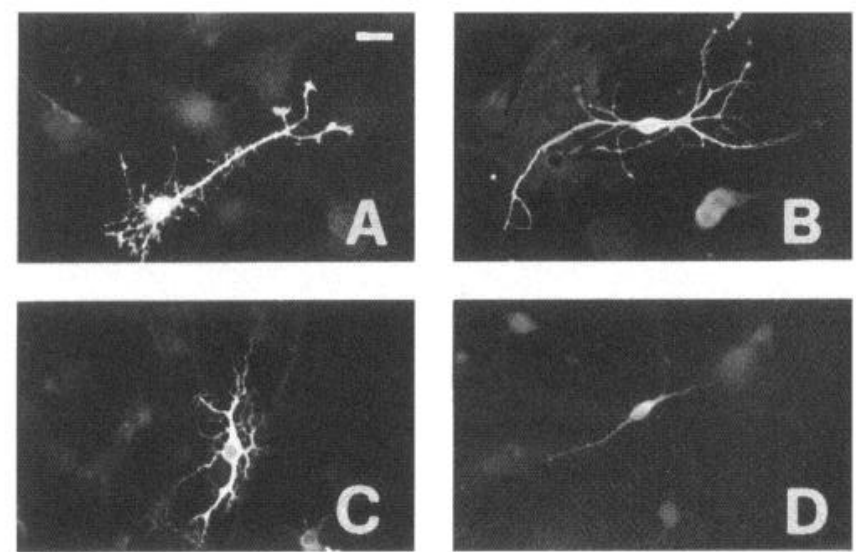

Figure 5. Neurotransmitter phenotype of bFGF-generated neuronal cells. Fluorescence micrographs of tertiary bFGF-generated spheres plated onto poly-o-coated coverslips and allowed to grow and differentiate for 10 DAP. Cells with neuronal morphology were found that were IR for glutamate $(A), \operatorname{GABA}(B)$, ChAT $(C)$, and SP $(D)$. Scale bar (shown in $A$ ), $16 \mu \mathrm{m}$.

primary spheres. From this we concluded that a majority of our bFGF-dependent cells are multipotent and that, although these precursors did not require factors other than bFGF to generate cells expressing neuronal antigens, removal of bFGF was necessary to achieve full differentiation of glial cells. Direct evidence for the multipotency of the bFGF-dependent precursors came from clonal analysis experiments (Fig. 4).

Even after removing bFGF, some spheres expressed only two cell types simultaneously (Table 2). It is conceivable that these spheres were generated by bipotential bFGF-dependent precursors (Vescovi et al., 1993) or, alternatively, by stem cells that failed to express their full developmental potential.

The neuronal nature of bFGF-generated neuron-like cells was investigated further by electrophysiological studies. Non-neuronal cells possess a vast array of voltage-gated ion channels (Ritchie, 1992). It is questionable, however, whether the mere presence of such channels can define excitability. A more realistic criterion is probably the presence of channel densities sufficiently high to sustain ion fluxes compatible with the membrane voltage changes observed under physiological firing. In astrocytes and glial cells, the $\mathrm{Na}^{+}$channels likely are inactivated at $V_{\text {rest }}$ and are present at a lower density than $\mathrm{K}^{+}$channels in neuronal cells (Sontheimer and Waxman, 1992; Sontheimer et al., 1992). Thus, in nonneuronal cells there is no excitability under physiological conditions. Conversely, in neurons the proportion of voltage-dependent excitatory and passive conductances should obey well defined rules (Belluzzi et al., 1985; Belluzzi and Sacchi, 1988). Thus, the active currents detected during our experiments on bFGFgenerated cells were fully compatible with our current-clamp observations. The spikes had a duration, afterhyperpolarization, and a well defined threshold that are typical features of neuronal spikes (Mason and Larkman, 1990; Belluzzi and Sacchi, 1991). Moreover, we observed at $V_{\text {rest }}$ spikes elicited by very brief current pulses typical of fast EPSCs (Griffith, 1990).

In our bFGF-generated cells, we detected immunoreactivity to GABA, SP, glutamate, and ChAT (Fig. 5) but failed to demonstrate immunoreactivity to Met-Enk, TH, or NPY. Thus, it appears that bFGF-dependent stem cells from the adult striatum generate neuron-like cells displaying multiple neurotransmitter phenotypes.
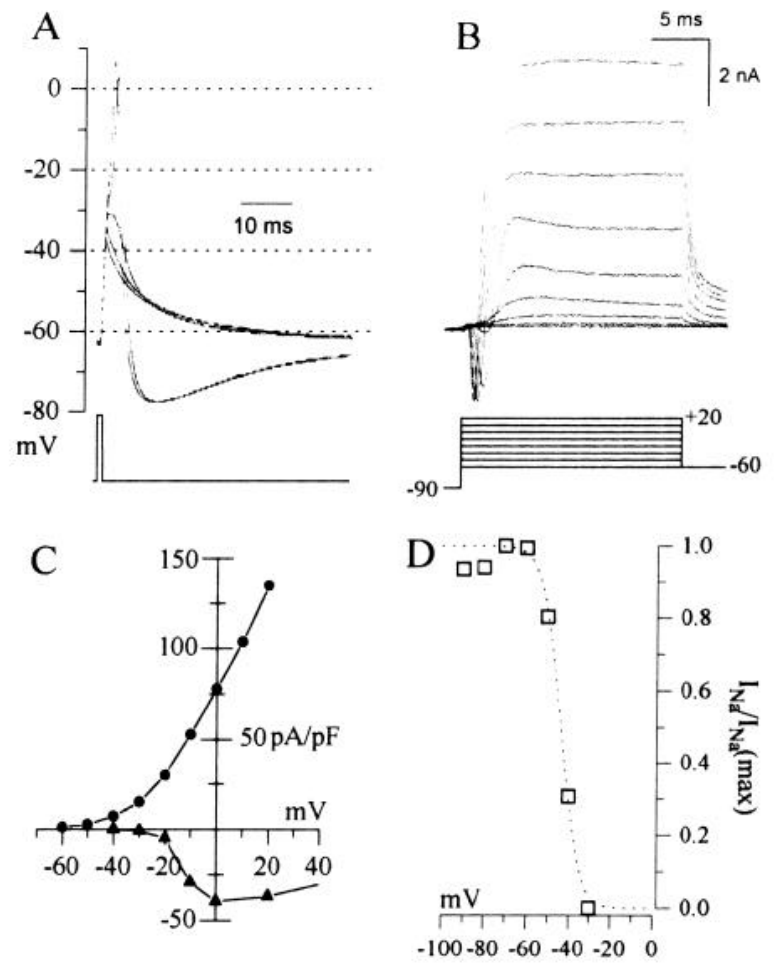

Figure 6. Regenerative responses and ionic currents in a bFGFgenerated neuron-like cell. $A$, Superimposed responses elicited from resting potential of $-63 \mathrm{mV}$ by brief current pulses $(1.5 \mathrm{nA})$ of increasing duration $(0.3,0.4,0.5,0.6$, and $0.7 \mathrm{msec})$. The threshold of the AP was positive to $-30 \mathrm{mV}$, which is in agreement with data shown by the current-voltage relationship $(C)$; furthermore, a large afterhyperpolarization to $-77 \mathrm{mV}$ is present. $B$, Superimposed traces of the currents elicited at test potentials from -60 to $+20 \mathrm{mV}$ (step $10 \mathrm{mV}$ ) from a holding potential of $-90 \mathrm{mV}$. $C$, Current-voltage relationship of the peak inward $(\boldsymbol{\Lambda})$ and long-lasting outward $(\bullet)$ currents shown in B. D, Steady-state inactivation of the peak inward current $\left(I_{\mathrm{Na}} / I_{\mathrm{Na}(\max )}\right)$. Data $(\square)$ were obtained from a double-pulse experiment (data not shown) in which the $I_{\mathrm{Na}}$ current was isolated after TTX application. The dotted line through the symbols is the Boltzmann curve, which best-fits the data with the following parameters: $V_{1 / 2}=-44 ; k_{\text {(slope) }}=4.8 \mathrm{mV}$. The cell had a capacitance of $58 \mathrm{pF}$ and an input resistance of $200 \mathrm{M} \Omega$.

Neural precursors have been isolated using bFGF in combination with serum from various regions of the adult mouse brain, including regions that do not comprise the subependyma (Richards et al., 1992). It is unclear, however, whether these are uni- or pluripotent (neuronal/glial) precursor cells or whether they can self-renew; nor is it known which neurotransmitter phenotypes their progeny can express. The differences between the behavior of these cells and that displayed by our bFGF-dependent stem cells strongly suggest that we are dealing with different cell types. Thus, serum was an absolute requirement for the bFGFdependent proliferation of the precursors described by Richards et al. (1992). In contrast, our cells underwent bFGF-dependent cell division and long-term self-renewal in serum-free medium, whereas they differentiated into glia and neurons when exposed to comparable concentrations of serum (A. Vescovi, unpublished data). Moreover, our bFGF-dependent stem cells did not require factors other than bFGF to give rise to mature neurons, whereas medium conditioned by the Ast-1 astrocytoma cell line was necessary for progenitors of Richards et al. (1992) to express neuronal markers. 
For their functional features, bFGF-dependent stem cells are similar to EGF-responsive cells of the adult mouse striatum (Reynolds et al., 1992). Although it is possible that there is no lineage relationship between these stem cells, the finding that the number of bFGF-dependent cells present is virtually the same as the number of EGF-responsive cells in our cultures lends support to the idea that these two stem cell populations are the same and are able to respond to multiple environmental stimuli. Alternatively, bFGF-dependent cells may arise in vivo from EGFresponsive elements, i.e., they may belong to the transit-dividing cell compartment and may acquire stem cell characteristics in the presence of bFGF. In fact, it has been suggested that transitdividing progenitor cells can re-enter the stem cell state (Potten and Loeffler, 1990). Indirect support for this idea comes from our recent observation that EGF-responsive stem cell progeny proliferate in vitro in the presence of bFGF and retain the capacity to generate neurons and both types of glia (Gritti et al., 1995). Experiments have begun that will assess the lineage relationship of EGF- and bFGF-dependent adult CNS stem cells.

Our study demonstrates that bFGF stimulates the division of multipotent stem cells from the adult striatum in vitro thus, we provide further evidence that the proliferation of progenitor cells of the adult brain can be controlled by several environmental factors. Because of the promiscuous nature of interactions among different types of FGF and the various FGF-receptor subtypes, other members of the $\mathrm{FGF}$ family might control the development of progenitors of the adult brain in vivo. Our findings extend the possibilities for isolating stem cclls from the adult CNS and may contribute to ascertaining the lineage relationships and functional properties of the multiple neural precursors now being found in the adult mammalian CNS.

\section{REFERENCES}

Allen $E$ (1912) The cessation of mitosis in the central nervous system of the albino rat. J Comp Neurol 22:547-568.

Altman J (1962) Are now neurons formed in the brains of adult mammals? Science 135:1127-1129.

Altman J (1969) Autoradiographic and histological studies of postnatal neurogenesis: cell proliferation and migration in the anterior forebrain, with special references to persisting neurogenesis in the olfactory bulb. J Comp Neurol 137:433-458.

Altman J, Bayer SA (1990) Migration and distribution of two populations of hippocampal granule cell precursors during the perinatal and postnatal periods. J Comp Neurol 301:365-381.

Altman J, Das GD (1965) Autoradiographic and histological evidence of postnatal hippocampal neurogenesis in rat. $\mathbf{J}$ Comp Neurol $124: 319-335$.

Anchan RM, Reh TA, Angello J, Balliet A, Walker M (1991) EGF and $\mathrm{TGF} \alpha$ stimulate retinal neuroepithelial cell proliferation in vitro. Neuron $6: 923-936$.

Baird A (1994) Fibroblast growth factors: activities and significance of non-neurotrophin neurotrophic growth factors. Curr Opin Neurobiol $4: 78-86$.

Bayer SA, Yakel SW, Puri PS (1982) Neurons in the rat dentate gyrus granular layer substantially increase during juvenile and adult life. Science 216:890-892.

Belluzzi O, Sacchi O (1988) The interaction between potassium and sodium currents in generating action potentials in the rat sympathetic neurones. J Physiol (I ond) 397:127-147.

Belluzzi O, Sacchi O (1991) A five-conductance model of the action potential in the rat sympathetic neurone. Prog Biophys Mol Biol $55: 1-30$.

Belluzzi O, Sacchi O, Wanke E (1985) Identification of delayed potassium and calcium currents in the rat sympathetic neuron under voltageclamp. J Physiol (Lond) 358:109-129.

Blakemore WF (1969) The ultrastructure of the subependymal plate in the rat. J Anat 104:423-433.
Corotto FS, Henegar JA, Maruniak JA (1993) Neurogenesis persists in the subependymal layer of the adult mouse brain. Neurosci Lett 149:111-114.

Frederiksen K, McKay RDG (1988) Proliferation and differentiation of rat neuroepithelial precursor cells in vivo. J Neurosci 8:1144-1151.

Genschwind DH, Hockfield S (1989) Identification of proteins that are developmentally regulated during early cerebral corticogenesis in the rat. J Neurosci 9:4303-4320.

Griffith WH (1990) Voltage-clamp analysis of posttetanic potentiation of the mossy fiber to $\mathrm{CA} 3$ synapse in hippocampus. J Neurophysiol 63:491-501.

Gritti A, Cova L, Parati EA, Galli R, Vescovi AL (1995) Basic fibroblast growth factor supports the proliferation of epidermal growth factorgenerated neuronal precursor cells of the adult mouse CNS. Neurosci Lett 185:151-154.

Hall PA, Watt FM (1989) Stem cells: the generation and renewal of cellular diversity. Development 106:619-633.

Hockfield S, McKay RDG (1985) Identification of major cell classes in the developing mammalian nervous system. J Neurosci 5:3310-3328.

Hooper ML (1992) Embryonal stem cells: introducing planned changes into the animal germ line. New York: Harwood Academic.

Huang L, Lim R (1990) Identification of injury-induced mitotic cells in adult rat cerebral cortex by neuron-specific markers. Dev Brain Res $51: 123-127$.

Islam MQ, Levan G (1987) A new fixation procedure for improved quality $\mathbf{G}$-bands in routine cytogenic work. Hereditas 107:127-130.

Kaplan MS (1981) Neurogenesis in the 3-month-old rat visual cortex. J Comp Neurol 195:323-338.

Kaplan MS, Hinds JW (1977) Neurogenesis in the adult rat: electron microscopy analysis of light radioautographs. Science 197:1092-1094.

1 ewis PD (1968) The fate of the subependymal cell in the adult rat brain, with a note on the origin of microglia. Brain 91:721-736.

Lillien L, Cepko C (1992) Control of proliferation in the retina: temporal changes in responsiveness to FGF and TGF $\alpha$. Development 115:253-266.

Lois C, Alvarez-Buylla A (1993) Proliferating subventricular zone cells in the adult mammalian forebrain can differentiate into neurons and glia. Proc Natl Acad Sci USA 90:2074-2077.

Lois C, Alvarez-Buylla A (1994) Long-distance migration in the adult mammalian brain. Science 264:1145-1148.

Luskin MB (1993) Restricted proliferation and migration of postnatally generated neurons derived from the forebrain subventricular zone. Neuron 11:173-189.

Mason A, Larkman A (1990) Correlations between morphology and electrophysiology of pyramidal neurons in slices of rat visual cortex. II. Electrophysiology. J Neurosci 10:1415-1428.

McConnell SK (1988) Development and decision-making in the mammalian cerebral cortex. Brain Res Rev 13:1-23.

McKay RDG (1989) The origins of cellular diversity in the mammalian central nervous system. Cell 58:815-821.

Morshead CM, Reynolds BA, Craig CG, McBurney MW, Staines WA, Morassutti D, Weiss S, van der Kooy D (1994) Neural stem cells in the adult mammalian forebrain: a relatively quiescent subpopulation of subependymal cells. Neuron 13:1071-1082.

Morshead CM, van der Kooy D (1992) Postmitotic death is the fate of constitutively proliferating cells in the subependymal layer of the adult mouse central nervous system. J Neurosei 12:249-256.

Okano HJ, Pfaff DW, Gibbs RB (1993) RB and cdc2 expression in brain: correlations with [ $\left.{ }^{3} I I\right]$ thymidine incorporation and ncurogencsis. J Neurosci 13:2930-2938.

Patterson JA, Privat A, Ling EA, Leblond P (1973) Transformation of subependymal cells into glial cells as shown by radioautography after ${ }^{3} \mathrm{H}$-thymidine injection into the lateral ventricle of the brain of young rats. J Comp Neurol 149:183-205.

Perraud F, Besnard F, Pettmann B, Sensenbrenner M, Labordette G (1988) Effects of acidic and basic fibroblast growth factors (aFGF and bFGF) on the proliferation and the glutamine synthetase expression of rat astroblasts in culture. Glia 1:124-131.

Potten CS, Loeffler M (1990) Stem cells: attributes, cycles, spirals, pitfalls and uncertainties: lessons for and from the crypt. Development 110:1001-1020.

Privat A, Leblond CP (1972) The subependymal layer and neighboring region in the brain of the young rat. J Comp Neurol 146:277-302.

Raedler E, Raedler A (1978) Autoradiographic study of early neurogenesis in rat cerebral cortex. Anat Embryol 154:267-312. 
Raff MC, Miller RH, Noble MD (1983) A glial progenitor cell that develops in vitro into an astrocyte or an oligodendrocyte depending on the culture medium. Nature 303:390-396.

Raff MC, Mirsky R, Fields KL, Lisak RP, Dorfman SI I, Silberberg BII, Gregson NA, Leibowitz S, Kennedy MC (1978) Galactocercbroside is a specific cell-surface antigenic marker for oligodendrocytes in culture. Nature 274:813-816.

Reynolds BA, Weiss S (1992) Gencration of neurons and astrocytes from isolated cells of the adult mammalian central nervous system. Science 255:1707-1710

Reynolds BA, Tetzlaff W, Weiss S (1992) A multipotent EGF-responsive striatal embryonic progenitor cell produces neurons and astrocytes. J Neurosci 12:4565-4574.

Richards KJ, Kilpatrick TJ, Bartlett PF (1992) De novo generation of neuronal cells from the adult mouse brain. Proc Natl Acad Sci USA 9:8591-8595

Ritchie JM (1992) Voltage-gated ion channels in Schwann cells and glia. Trends Neurusci 15:345-351.

Robertson EJ, Kaufman MH, Bradley A, Evans MJ (1983) Isolation, properties and karyotype analysis of pluripotential cell lines from nor mal and parthenogenetic embryos. In: Teratocarcinoma stem cells: Cold Spring Harbor Conferences on Cell Proliferation, Vol 10) (Silver LM, Martin GR, Strickland S, eds), pp 647-663. Cold Spring Harbor, NY: Cold Spring Harbor Laboratory.

Smart I (1961) The subependymal layer of the mouse brain and its cell production as shown by radioautography after ${ }^{3} \mathrm{H}$-thymidine injection. J Comp Neurol 116:325-338.
Smart 1, Leblond CP (1961) Evidence for division and transformation of neuroglia cells in the mouse brain as derived from radioatography after injection with ${ }^{3} \mathrm{H}$-thymidine. J Comp Neurol 116:359-366.

Sontheimer H, Waxman SG (1992) Ion clannels in spinal cord astrocytes in vitro. II. Biophysical and pharmacological analysis of two $\mathrm{Na}^{+}$currents types. J Neurophysiol 68:1001-1011.

Sontheimer H, Black JA, Ransom BRL, Waxman SG (1992) Ion channels in spinal cord astrocytes in vitro. I. Transient expression of high levels of $\mathrm{Na}$ and $\mathrm{K}^{+}$channels. J Neurophysiol 68:985-1000).

Stemple DL, Anderson DJ (1992) Isolation of a stem cell for neurons and glia from the mammalian neural crest. Cell 71:1-20.

Sturrock RR, Smart IIIM (1980) A morphological study of the mousc subependymal layer from the embryonic life to old age. J Anat 1.30:391-415.

Tohyama T, Lee VMY, Rorke LB, Marvin M, McKay RDG, Irojanovsky JQ (1992) Nestin cxpression in embryonic human neuroepithelium and in human neurocpithelium tumor cells. Lab Invest 66:303-313.

Vescovi AL, Reynolds BA, Fraser DD, Weiss S (1993) bFGF regulates the proliferative fate of unipotent (neuronal) and bipotent (neuronal/astroglial) EGF-generated CNS progenitor cells. Neuron 11:951-966.

Wanke E, Ferroni A, Malgaroli A, Ambrosini A. Pozzan T, Meldolesi J (1987) Activation of a muscarinic receptor selectively inhibits a rapidly inactivated $\mathrm{Ca}^{2+}$ current in rat sympathetic neurons. Proc Natl Acad Sci USA $84: 4313-4317$. 